\title{
THIRTY-NINTH ANNUAL LIST OF PAPERS
}

READ BEFORE THE AMERICAN MATHEMATICAL SOCIETY AND SUBSEQUENTLY PUBLISHED, INCLUDING REFERENCES TO THE PLACES OF PUBLICATION

Agnew, R. P. On uniform summability of sequences of continuous functions. Read April 18, 1930. This Bulletin, vol. 36, No. 8, pp. 529-532; Aug., 1930. The behavior of bounds and oscillations of sequences of functions under regular transformations. Read April 18, 1930. Transactions of this Society, vol. 32, No. 4, pp. 669-708; Oct., 1930.

Albert, A. A. Normal division algebras in $4 p^{2}$ units, $p$ an odd prime. Read Dec. 27, 1928. Annals of Mathematics, (2), vol. 30, No. 4, pp. 583-590; Oct., 1929.

- The structure of any algebra which is a direct product of rational generalized quaternion division algebras. Read March 30,1929. Annals of Mathematics, (2), vol. 30, No. 4, pp. 621-625; Oct., 1929.

- Determination of all normal division algebras in thirty-six units of type $R_{2}$. Read Dec. 27, 1928. American Journal of Mathematics, vol. 52, No. 2, pp. 283-292; April, 1930.

- On the structure of pure Riemann matrices with non-commutative multiplication algebras. Read Oct. 26, 1929. Proceedings of the National Academy of Sciences, vol. 16, No. 4, pp. 308-312; April, 1930.

- On direct products, cyclic division algebras, and pure Riemann matrices. Read April 18, 1930. Proceedings of the National Academy of Sciences, vol. 16, No. 4, pp. 313-315; April, 1930.

- New results in the theory of normal division algebras. Read Dec. 27, 1929. Transactions of this Society, vol. 32, No. 2, pp. 171-195; April, 1930.

- The non-existence of pure Riemann matrices with normal multiplication algebras of order sixteen. Read Dec. 27, 1929. Annals of Mathematics, (2), vol. 31, No. 3, pp. 375-380; July, 1930.

- The integers of normal quartic fields. Read Dec. 27, 1929. Annals of Mathematics, (2), vol. 31, No. 3, pp. 381-418; July, 1930.

- A necessary and sufficient condition for the non-equivalence of any two rational generalized quaternion division algebras. Read Feb. 22, 1930. This Bulletin, vol. 36, No. 8, pp. 535-540; Aug., 1930.

Altshiller-Court, N. On five mutually orthogonal spheres. Read Sept. 6, 1928. Annals of Mathematics, (2), vol. 30, No. 4, pp. 613-620; Oct., 1929.

- La sphère de Longchamps: une définition. Read Dec. 27, 1928. L'Enseignement Mathématique, vol. 39, Nos. 1-3, pp. 31-34; Aug., 1930.

Archibald, R. C. Mathematics before the Greeks. Read Dec. 30, 1929. Science, new ser., vol. 71, No. 1831, pp. 109-121; Jan. 31, 1930.

Arnold, H. E. Concerning the rational curves $R_{3}{ }^{5}(I I)$ and $R_{2}{ }^{4}$. Read Oct. 27, 1928. American Journal of Mathematics, vol. 52, No. 3, pp. 601-606; July, 1930. 
Ayres, W. L. Concerning continuous curves in metric space. Read Sept. 9, 1927. American Journal of Mathematics, vol. 51, No. 4, pp. 577-594; Oct., 1929.

Continuous curves homeomorphic with the boundary of a plane domain. Read March 30, 1929. Fundamenta Mathematicae, vol. 14, pp. 92-95; 1929.

- On continuous images of a compact metric space. Read Aug. 30, 1929. Fundamenta Mathematicae, vol. 14, pp. 334-338; 1929.

- On the density of the cut points and end points of a continuum. Read Aug. 30, 1929. This Bulletin, vol. 36, No. 10, pp. 659-667; Oct.,1930.

BABcock, R. W. Thermal convection. Read April 11, 1925. Physical Review, (2), vol. 35, No. 7, pp. 1008-1013; April 15, 1930.

Ballantine, J. P. A graphical derivation of Cramer's rule. Read June 20, 1929. American Mathematical Monthly, vol. 36, No. 8, pp. 439-441; Oct., 1929.

BAMForth, F. R. Surface transformations. Read Dec. 27, 1929. Transactions of this Society, vol. 32, No. 3, pp. 417-450; July, 1930.

BAMForth, F. R., and BirkhofF, G. D. Divergent series and singular points of ordinary differential equations. Read March 29, 1929. Transactions of this Society, vol. 32, No. 1, pp. 114-146; Jan., 1930.

BARNETT, I. A. The transformations generated by an infinitesimal projective transformation in function space. Read April 6, 1928. This Bulletin, vol. 36, No. 4, pp. 273-276; April, 1930.

BAsoco, M. A. On certain finite sums of binomial coefficients and gamma functions. Read April 5, 1930. American Mathematical Monthly, vol. 37, No. 5, pp. 241-245; May, 1930.

Bateman, H. Some properties of spherical harmonics. Read June 20, 1929. This Bulletin, vol. 36, No. 4, pp. 306-314; April, 1930.

BAteN, W. D. Simultaneous treatment of discrete and continuous probability by use of Stieltjes integrals. Read Nov. 30,1929. Annals of Mathematical Statistics, vol. 1, No. 1, pp. 95-100; Feb., 1930.

The evaluation of certain definite integrals by the use of probability functions. Read Aug. 29, 1929. This Bulletin, vol. 36, No. 6, pp. 433440; June, 1930.

BELL, C. In- and circumscribed sets of planes to space curves. Read Nov. 29, 1929. This Bulletin, vol. 36, No. 6, pp. 409-412; June, 1930.

- Polygons jointly related to the rational cubics and other curves. Read June 20, 1929. Annals of Mathematics, (2), vol. 31, No. 3, pp. 344-346; July, 1930.

BeLL, E. T. A class of polynomials and rational functions in eight variables. Read Dec. 31, 1928. Tôhoku Mathematical Journal, vol. 31, Nos. 3-4, pp. 321-329; Aug., 1929.

- Theorems on total representations as sums of square or triangular numbers. Read June 20, 1929. American Mathematical Monthly, vol. 36. No. 8, pp. 424-426; Oct., 1929. 
On the representations of $4 t+2$ as a sum of $4 s$ squares. Read June 20, 1929. Journal of the London Mathematical Society, vol. 4, No. 4, pp. 279284; Oct., 1929.

- Numbers of representations of integers in a certain triad of ternary quadratic forms. Read Nov. 29, 1929. Transactions of this Society, vol. 32, No. 1, pp. 1-5; Jan., 1930.

- Numbers of representations in certain quinary quadratic forms. Read Nov. 29, 1929. American Journal of Mathematics, vol. 52, No. 2, pp. 271279; April, 1930.

- Three degeneracies in the theory of ternary quadratic arithmetical forms. Read Nov. 29, 1929. Annals of Mathematics, (2), vol. 31, No. 2, pp. 190192; May, 1930.

- A correspondence between irregular fields. Read April 5, 1930. This Bulletin, vol. 36, No. 5, pp. 415-419; June, 1930.

- The real unit segment as a number field. Read April 5, 1930. American Journal of Mathematics, vol. 52, No. 3, pp. 548-550; July, 1930.

- Analytic functions in the irregular field of all numerical functions. Read April 5, 1930. Transactions of this Society, vol. 32, No. 4, pp. 869-878; Oct., 1930.

- Numbers of representations in certain senary quadratic forms. Read April 5, 1930. This Bulletin, vol. 36, No. 12, pp. 883-886; Dec., 1930.

Benton, T. C. A definition of an unknotted simple closed curve. Read March 30, 1929. This Bulletin, vol. 36, No. 6, pp. 406-408; June, 1930.

- On continuous curves which are homogeneous except for a finite number of points. (Second part.) Read Oct. 29, 1927, and Oct. 27, 1928. Fundamenta Mathematicae, vol. 15, pp. 38-41; 1930.

Birkhoff, G. D. See BAmforth, F. R.

Bliss, G. A. An integral inequality. Read March 29, 1929. Journal of the London Mathematical Society, vol. 5, No. 1, pp. 40-46; Jan., 1930.

Blue, A. H. On the structure of sets of points of classes one, two, and three. Read Dec. 30, 1929. Mathematische Annalen, vol. 102, No. 4, pp. 624632; Dec., 1929.

Blumberg, $\mathrm{H}$. On a complete characterization of the set of points of unbounded grade of an arbitrary surface. Read April 16, 1927. This Bulletin, vol. 36, No. 10, pp. 655-658; Oct., 1930.

Methods in point sets and the theory of real functions. Read April 18, 1930. This Bulletin, vol. 36, No. 12, pp. 809-830; Dec., 1930.

Brenke, W. C. On polynomial solutions of a class of linear differential equations of the second order. Read Nov. 26, 1927, and Dec. 1, 1928. This Bulletin, vol. 36, No. 2, pp. 77-84; Feb., 1930.

BRown, A. B. Relations between the critical points of a real analytic function of $n$ independent variables. Read June 20,1929. American Journal of Mathematics, vol. 52, No. 2, pp. 250-270; April, 1930.

- Coalescence of parts of a complex. Read April 18, 1930. Proceedings of the National Academy of Sciences, vol. 16, No. 6, pp. 401-406; June, 1930. 
An extension of the Alexander duality theorem. Read June 20, 1930. Proceedings of the National Academy of Sciences, vol. 16, No. 6, pp. 407408; June, 1930.

Relations between the critical points and curves of a real analytic function of two independent variables. Read Oct. 26, 1929. Annals of Mathematics, (2), vol. 31, No. 3, pp. 449-456; July, 1930.

Browne, E. T. On the signature of a quadratic form. Read March 30, 1929. Annals of Mathematics, (2), vol. 30, No. 4, pp. 517-525; Oct., 1929.

- On the separation property of the roots of the secular equation. Read Sept. 11, 1930. American Journal of Mathematics, vol. 52, No. 4, pp. 843850; Oct., 1930.

The characteristic roots of a matrix. Read Sept. 11, 1930. This Bulletin, vol. 36, No. 10, pp. 705-710; Oct., 1930.

Buchanan, D. Periodic orbits in the problem of three bodies with repulsive and attractive forces. Read June 20,1930. American Journal of Mathematics, vol. 52, No. 4, pp. 899-913; Oct., 1930.

Buchanan, H. E. On a certain function of the masses in the problem of three bodies. Read Aug. 30, 1929. American Journal of Mathematics, vol. 51, No. 4, pp. 595-598; Oct., 1929.

CaIrns, S. S. The cellular division and approximation of regular spreads. Read June 20, 1930. Proceedings of the National Academy of Science, vol. 16, No. 7, pp. 488-491; July, 1930.

CAjori, F. New data on the origin and spread of the dollar mark. Read June 20, 1929. Scientific Monthly, vol. 29, No. 3, pp. 212-216; Sept., 1929.

- Generalizations in geometry as seen in the history of developable surfaces. Read June 20, 1929. American Mathematical Monthly, vol. 36, No. 8, pp. 431-437; Oct., 1929.

- Absurdities due to division by zero. An historical note. Read June 20, 1929. Mathematics Teacher, vol. 22, No. 6, pp. 366-368; Oct., 1929. History of determinations of the heights of mountains. Read Oct. 27, 1928. Isis, vol. 12, No. 3, pp. 482-514; Dec., 1929.

- Newton's idea of God in the different editions of the Principia. Read Nov. 29, 1929. Open Court, vol. 44, No. 2, pp. 65-72; Feb., 1930.

Calugaréano, G. On differential equations admitting polygenic integrals. Read Dec. 27, 1929. Transactions of this Society, vol. 32, No. 1, pp. 110113; Jan., 1930.

Carlitz, L. On Galois fields of certain types. Read April 18, 1930. Transactions of this Society, vol. 32, No. 3, pp. 451-472; July, 1930.

Carmichael, R. D. Finite geometries and the theory of groups. Read Dec. 29, 1925. American Journal of Mathematics, vol. 52, No. 4, pp. 745-788; Oct., 1930.

Concerning quasi- $k$-fold transitivity of permutation groups. Read Sept. 11, 1930. This Bulletin, vol. 36, No. 12, pp. 857-862; Dec., 1930.

Carpenter, A. F. Note on ruled surfaces and their developables. Read June 20, 1930. This Bulletin, vol. 36, No. 8, pp. 525-528; Aug., 1930. 
CoHen, L. W. A characterization of those subsets of metric separable space which are homeomorphic with subsets of the linear continuum. Read April 7, 1928. Fundamenta Mathematicae, vol. 14, pp. 281-303; 1929.

- A note on a system of equations with infinitely many unknowns. Read Oct. 26, 1929. This Bulletin, vol. 36, No. 8, pp. 563-572; Aug., 1930.

Соок, A. J. Pairs of rectilinear congruences with generators in one-to-one correspondence. Read June 20, 1929. Transactions of this Society, vol. 32, No. 1, pp. 31-46; Jan., 1930.

Copeland, A. H. Independent event histories. Read Sept. 6, 1928. American Journal of Mathematics, vol. 51, No. 4, pp. 612-618; Oct., 1929.

Court, N. A. See Altshiller-Court, N.

Craig, C. C. The semi-invariants and moments of incomplete normal and type III frequency functions. Read Oct. 26, 1929. Annals of Mathematics, (2), vol. 32, No. 2, pp. 251-270; May, 1$) 30$.

Cralg, H. V. On the solution of the Euler equations for their highest derivatives. Read Sept. 7, 1928. This Bulletin, vol. 36, No. 8, pp. 558-562; Aug., 1930.

Cramlet, C. M. The invariants of an $n$-ary $q$-ic differential form. Read March 29, 1929. Annals of Mathematics, (2), vol. 31, No. 1, pp. 134-150; Jan., 1930.

Curry, H. B. Grundlagen der kombinatorischen Logik. Teil I. Read Dec. 27, 1929. American Journal of Mathematics, vol. 52, No. 3, pp. 509-536; July, 1930.

- Grundlagen der kombinatorischen Logik. Teil II. Read Dec. 27, 1929. American Journal of Mathematics, vol. 52, No. 4, pp. 789-834; Oct., 1930.

DAvies, G. R. The analysis of frequency distributions. Read Dec. 30, 1929. Journal of the American Statistical Association, new ser., vol. 24, No. 168, pp. 349-366; Dec., 1929.

DAvis, H. T. Differential equations of infinite order with constant coefficients. Read Aug. 29, 1929. American Journal of Mathematics, vol. 52, No. 1, pp. 97-108; Jan., 1930.

Davis, H. T., and Latshaw, V. V. Formulas for the fitting of polynomials to data by the method of least squares. Read Nov. 29, 1929. Annals of Mathematics, (2), vol. 31, No. 1, pp. 52-78; Jan., 1930.

Dickson, L. E. Construction of division algebras. Read Feb. 22, 1930. Transactions of this Society, vol. 32, No. 2, pp. 319-334; April, 1930.

Dines, L. L. On linear integral inequalities of first kind. Read Sept. 6, 1928. Transactions of the Royal Society of Canada, vol. 23, section III, No. 2, pp. 141-146; May, 1929.

- Linear inequalities and some related properties of functions. Read Dec. 31, 1929. This Bulletin, vol. 36, No. 6, pp. 393-405; June, 1930.

Dodn, E. L. Probability as expressed by asymptotic limits of pencils of sequences. Read Aug. 27, 1929. This Bulletin, vol. 36, No. 4, pp. 299-305; April, 1930. 
DorroH, J. L. Concerning a set of axioms for the semi-quadratic geometry of a three-space. Read Sept. 6, 1928. This Bulletin, vol. 36, No. 10, pp. 719721 ; Oct., 1930.

Dorwart, H. L., and Neelley, J. H. Discussion of a construction of the rational plane quintic. Read Dec. 27, 1928. Tôhoku Mathematical Journal, vol. 32, Nos. 1-2, pp. 86-96; Dec., 1929.

Dye, L. A. Involutorial transformations in $S_{3}$ of order $n$ with an $(n-1)$-fold line. Read Feb. 22, 1930. Transactions of this Society, vol. 32, No. 2, pp. 251-261; April, 1930.

EARL, J. M. Polynomials of best approximation on an infinite interval. Read April 7, 1928. Transactions of this Society, vol. 32, No. 4, pp. 888-904; Oct., 1930.

Edmonson, N. Poisson's integral and plurisegments on the hypersphere. Read Sept. 7, 1928. Annals of Mathematics, (2), vol. 31, No. 1, pp. 13-31; Jan., 1930.

EldER, J. D. Arithmetized trigonometrical expansions of doubly periodic functions of the third kind. Read Nov. 29, 1929. Proceedings of the National Academy of Sciences, vol. 15, No. 8, pp. 675-677; Aug., 1929.

Емсн, A. On the geometry of symmetric functions. Read March 29, 1929. Tôhoku Mathematical Journal, vol. 32, Nos. 1-2, pp. 16-26; Dec., 1929.

- On algebraic surfaces which are invariant in a certain class of finite collineation groups. Read April 18, 1930. This Bulletin, vol. 36, No. 8, pp. 547-552; Aug., 1930.

Engstrom, H. T. On the common index divisors of an algebraic field. Read Dec. 27, 1928, and March 30, 1929. Transactions of this Society, vol. 32, No. 2, pp. 223-237; April, 1930.

- On the generalization of trigonometric identities in arithmetical paraphrasing. Read April 5, 1930. This Bulletin, vol. 36, No. 10, pp. 667-672; Oct., 1930.

- The theorem of Dedekind in the ideal theory of Zolotarev. Read Nov. 29, 1929. Transactions of this Society, vol.32, No.4, pp. 879-887; Oct., 1930.

Evans, G. C., and Smiley, W. G. The first variation of a functional. Read Feb. 22, 1930. This Bulletin, vol. 36, No. 6, pp. 427-433; June, 1930.

Feenberg, E. A general system of ordinary differential equations of the first order. Read Sept. 7, 1928. American Journal of Mathematics, vol. 52, No. 3, pp. 635-646; July, 1930.

Feld, J. M., and Newman, P. On the representation of analytic functions of several variables as infinite products. Read Oct. 26, 1929. This Bulletin, vol. 36, No. 4, pp. 284-288; April, 1930.

FÉRAud, L. On Birkhoff's Pfaffian systems. Read Sept. 11, 1930. Transactions of this Society, vol. 32, No. 4, pp. 817-831; Oct., 1930.

Fisher, I. The application of mathematics to the social sciences. Read Dec. 31, 1929. This Bulletin, vol. 36, No. 4, pp. 225-243; April, 1930.

FORT, T. The general theory of factorial series. Read Oct. 26, 1929. This Bulletin, vol. 36, No. 4, pp. 244-258; April, 1930. 
Foster, M. Theorems on inverted and rotated congruences. Read April 18, 1930. This Bulletin, vol. 36, No. 8, pp. 587-592; Aug., 1930.

Franklin, P. The operators of quantum mechanics. Read Oct. 27, 1928. Journal of Mathematics and Physics of the Massachusetts Institute of Technology, vol. 8, No. 3, pp. 235-245; Oct., 1929.

Dynamical systems with integrals quadratic in the velocities. Read Dec. 27, 1929. Journal of Mathematics and Physics of the Massachusetts Institute of Technology, vol. 9, No. 4, pp. 333-344; Sept., 1930.

Franklin, P., and Moore, C. L. E. Systems of linear partial differential equations. Read Oct. 26, 1929. Journal of Mathematics and Physics of the Massachusetts Institute of Technology, vol. 9, No. 1, pp. 22-46; Feb., 1930.

FrINK, O. The fourth postulates of Riesz and Hausdorff. Read Dec. 27, 1929. This Bulletin, vol. 36, No. 4, pp. 281-283; April, 1930.

Garver, R. Transformations on cubic equations. Read Aug. 29, 1929. American Mathematical Monthly, vol. 36, No. 7, pp. 366-369; Aug.-Sept., 1929.

- On the Brioschi normal quintic. Read June 20,1929. Annals of Mathematics, (2), vol. 30, No. 4, pp. 607-612; Oct., 1929.

On the transformation which leads from the Brioschi quintic to a general principal quintic. Read Nov. 29, 1929. This Bulletin, vol. 36, No. 2, pp. 115-119; Feb., 1930.

- Quartic equations with the alternating group. Read Aug. 29, 1929. Tôhoku Mathematical Journal, vol. 32, Nos. 3-4, pp. 306-311; June, 1930. - Concerning polynomial functions with certain properties. Read Nov. 29, 1929. Annals of Mathematics, (2), vol. 31, No. 3, pp. 366-370; July, 1930.

Gehman, H. M. Centers of symmetry in analysis situs. Read Nov. 29, 1929. American Journal of Mathematics, vol. 52, No. 3, pp. 543-547; July, 1930.

Gergen, J. J. Mapping of a general type of three dimensional region on a sphere. Read Feb. 25, 1928. American Journal of Mathematics, vol. 52 No. 2, pp. 197-224; April, 1930.

Gergen, J. J., and Mandelbrojt, S. Sur les fonctions définies par une série de Dirichlet. Read Dec. 29, 1926 . Comptes Rendus de l'Académie des Sciences, vol. 189, No. 24, pp. 1057-1059; Dec. 9, 1929.

GHosh, S. On the solution of the equations of elastic equilibrium suitable for elliptic boundaries. Read Feb. 25, 1928. Transactions of this Society, vol. 32, No. 1, pp. 47-60; Jan., 1930.

GILL, B. P. An analogue for algebraic functions of the Thue-Siegel theorem. Read March 29, 1929. Annals of Mathematics, (2), vol. 32, No. 2, pp. 207-218; May, 1930.

Gillespie, D. C., and Hurwitz, W. A. On sequences of continuous functions having continuous limits. Read Dec. 27, 1929. Transactions of this Society, vol. 32, No. 3, pp. 527-543; July, 1930.

Gourin, E. On irreducible polynomials in several variables which become reducible when the variables are replaced by powers of themselves. Read Feb. 23, 1929. Transactions of this Society, vol. 32, No. 3, pp. 485-501; July, 1930. 
Graustein, W. C. A geometrical problem in which order of choice is important. Read Sept. 6, 1928. American Mathematical Monthly, vol. 35, No. 8, pp. 412-415; Oct., 1928.

- Méthodes invariantes dans la géométrie infinitésimale des surfaces. Read Dec. 27, 1923. Académie Royale de Belgique, Classe des Sciences, Mémoires in 8vo, vol. 11, No. 1, pp. 1-96; 1929.

The linear element of a Riemannian $V_{n}$ in terms of the Christoffel symbols of the second kind. Read Dec. 28, 1926. American Journal of Mathematics, vol. 52, No. 2, pp. 351-356; April, 1930.

_- Invariant methods in classical differential geometry. Read April 18, 1930. This Bulletin, vol. 36, No. 8, pp. 489-521; Aug., 1930.

Graves, L. M. Discontinuous solutions in space problems of the calculus of variations. Read Sept. 9, 1927, and April 7, 1928. American Journal of Mathematics, vol. 52, No. 1, pp. 1-28; Jan., 1930.

- Discontinuous solutions in the calculus of variations. Read Nov. 29, 1929. This Bulletin, vol. 36, No. 12, pp. 831-846; Dec., 1930.

Griffiths, L. W. A generalization of the Fermat theorem on polygonal numbers. Read Dec. 31, 1928. Annals of Mathematics, (2), vol. 31, No. 1, pp. 1-12; Jan., 1930.

Groat, B. F. Theory of similarity and models. Read Dec. 27, 1929. Proceedings of the American Society of Civil Engineers, 1930, p. 1803.

Gronwall, T. H. Zur Gibbschen Erscheinung. Read Feb. 28, 1925, and May 1, 1926. Annals of Mathematics, (2), vol. 31, No. 2, pp. 233-240; May, 1930.

On Minkowski's mixed volume of three convex solids. Read June 17, 1920. Annals of Mathematics, (2), vol. 31, No. 3, pp. 470-474; July, 1930.

- A formula in geometrical optics. Read Oct. 26, 1929. Annals of Mathematics, (2), vol. 31, No. 3, pp. 475-478; July, 1930.

Grove, V. G. A canonical form of Green's projective analogue of the Gauss differential equations. Read Dec. 31, 1928. Transactions of this Society, vol. 32, No. 3, pp. 473-484; July, 1930.

- On canonical forms of differential equations. Read April 19, 1930. This Bulletin, vol. 36, No. 8, pp. 582-586; Aug., 1930.

Hart, W. L. Limited tri-linear forms in Hilbert space. Read June 20, 1929. American Journal of Mathematics, vol. 52, No. 3, pp. 563-570; July, 1930.

Hazlett, O. C. On division algebras. Read May 2, 1925. Transactions of this Society, vol. 32, No. 4, pp. 912-925; Oct., 1930.

HEDRICK, E. R. On certain properties of non-analytic functions of a complex variable. Read Oct. 29, 1927. Bulletin of the Calcutta Mathematical Society, vol. 20, pp. 109-124; 1928.

Hedrick, E.R., and INGOLd, L. Concerning the Michelson-Morley experiment. Read Dec. 2, 1922. Astrophysical Journal, vol. 68, No. 5, pp. 374-382; Dec., 1928; Contributions from the Mount Wilson Observatory, No. 373, pp. 34-42, 1928. 
Hille, E., and Tamarkin, J. D. On the theory of linear integral equations. I. Read Dec. 27, 1929. Annals of Mathematics, (2), vol. 31, No. 3, pp 479-528; July, 1930.

Holl, D. L. Viscous fluid motion in eccentric cylinders. Read Nov. 27, 1926. University of Chicago Abstracts of Theses, science series, vol. 4, pp. 15-19; 1925-26.

Hollcroft, T. R. The lines of an algebraic surface. Read Feb. 25, 1928. Messenger of Mathematics, vol. 58, No. 6, pp. 81-88; Oct., 1928.

— Invariant postulation. Read Oct. 27, 1928. This Bulletin, vol. 36, No. 6, pp. 421-426; June, 1930.

Hotelling, $\mathrm{H}$. The consistency and ultimate distribution of optimum statistics. Read Dec. 30, 1929. Transactions of this Society, vol. 32, No. 4, pp. 847-859; Oct., 1930.

Hurwitz, S. Algebraic first integrals of algebraic differential equations. Read March 29, 1929. American Mathematical Monthly, vol. 37, No. 4, pp. 185187; April, 1930.

Hurwitz, W. A. The oscillation of a sequence. Read Dec. 27, 1929. American Journal of Mathematics, vol. 52, No. 3, pp. 611-616; July, 1930.

- See Gillespie, D. C.

Ingold, L. See Hedrick, E. R.

IngRaham, M. H. An elementary theorem on matrices. Read Sept. 11, 1930. This Bulletin, vol. 36, No. 10, pp. 673-674; Oct., 1930.

JACKsON, D. On certain problems of approximation in the complex domain. Read Dec. 29, 1927. This Bulletin, vol. 36, No. 12, pp. 851-857; Dec., 1930.

- The theory of approximation. Read April 11 and Sept. 8-12, 1925. American Mathematical Society Colloquium Publications, vol. 11; 1930. $8+178 \mathrm{pp}$.

JAEger, C. G. A character symbol for primes relative to a cubic field. Read Dec. 28, 1927. American Journal of Mathematics, vol. 52, No. 1, pp. 85-96; Jan., 1930.

James, G. Generalizations of Pascal's and Brianchon's theorems. Read June 20, 1929. American Mathematical Monthly, vol. 37, No. 2, pp. 78-80; Feb., 1930.

James, G. O. Euclidean approximations to Einsteinian motion in the solar field. Read Nov. 26, 1927. Astronomical Journal, vol. 39, No. 13, pp. 111-114; May 25, 1929.

JEFFERY, R. L. The continuity of a function defined by a definite integral. Read Dec. 27, 1928. Proceedings of the London Mathematical Society, (2), vol. 31, No. 1, pp. 18-22; May 28, 1930.

Jerbert, A. R. Quadruples of space curves. Read June 2, 1928. American Journal of Mathematics, vol. 52, No. 1, pp. 136-149; Jan., 1930.

Jones, B. W. Certain quinary forms related to the sum of five squares. Read April 5, 1930. This Bulletin, vol. 36, No. 10, pp. 721-734; Oct., 1930. 
Kaplan, C., and Murnaghan, F. D. On the fundamental constitutive equations in electromagnetic theory. Read April 7, 1928. Physical Review, vol. 35, No. 7, pp. 763-777; April 1, 1930.

KellogG, O. D., and Vasilesco, F. A contribution to the theory of capacity. Read Dec. 27, 1928. American Journal of Mathematics, vol. 51, No. 4, pp. 515-526; Oct., 1929.

Kimball, B. F. Geodesics on a toroid. Read Oct. 30, 1926. American Journal of Mathematics, vol. 52, No. 1, pp. 29-52; Jan. 1930.

Knebelman, M. S. Collineations and motions in generalized spaces. Read Sept. 6, 1928. American Journal of Mathematics, vol. 51, No. 4, pp. 527564 ; Oct., 1929.

- Content-preserving transformations. Read Dec. 27, 1929. Proceedings of the National Academy of Sciences, vol. 16, No. 2, pp. 156-159; Feb., 1930.

- On groups of motion in related spaces. Read Sept. 6, 1928. American Journal of Mathematics, vol. 52, No. 2, pp. 280-282; April, 1930.

Kramer, E. Polygenic functions of the dual variable $w=u+j v$. Read Feb. 23, 1929. American Journal of Mathematics, vol. 52, No. 2, pp. 370-376; April, 1930.

- The Laguerre group. Read Feb. 23, 1929. Privately printed, 1930. 15 pp. (With preceding paper, forms Columbia University Dissertation.)

Lamson, K. W. Some differential and algebraic consequences of the Einstein field equations. Read Dec. 27, 1923, and Sept. 12, 1930. Transactions of this Society, vol. 32, No. 4, pp. 709-722; Oct., 1930.

LANE, E. P. Hypergeodesic mapping of a surface on a plane. Read April 18, 1930. Transactions of this Society, vol. 32, No. 3, pp. 558-568; July, 1930.

- Integral surfaces of pairs of partial differential equations of the third order. Read Dec. 30, 1929. Transactions of this Society, vol. 32, No. 4, pp. 782-793; Oct., 1930.

Langdon, W. L., and Ore, O. Semi-invariants and Sheppard's correction. Read Oct. 26, 1929. Annals of Mathematics, (2), vol. 31, No. 2, pp. 230232. May, 1930.

LANGER, R. E. The boundary problem associated with a differential system rational in the parameter. Read Sept. 7, 1928. Transactions of this Society, vol. 32, No. 2, pp. 238-250; April, 1930.

LAPAZ, L. An inverse problem of the calculus of variations for multiple integrals. Read Aug. 29, 1929, and Feb. 22, 1930. Transactions of this Society, vol. 32, No. 3, pp. 509-519; July, 1930.

- Problems of the calculus of variations with prescribed transversality conditions. Read Aug. 29, 1929. This Bulletin, vol. 36, No. 10, pp. 674680; Oct., 1930.

LAtimer, C. G. A generalization of Eisenstein's canonical cubic and associated forms. Read Sept. 6, 1928. American Journal of Mathematics, vol. 52, No. 1, pp. 127-136; Jan., 1930.

- On the class number of cubic cyclotomic fields. Read Aug. 29, 1929. Annals of Mathematics, (2), vol. 31, No. 3, pp. 347-354; July, 1930. 
On certain identities in theta functions. Read March 30 and Dec. 27, 1929. Transactions of this Society, vol. 32, No. 4, pp. 832-846; Oct., 1930.

Latshaw, V. V. See Davis, H. T.

Lehmer, D. H. On the $r$-th divisors of a number. Read Oct. 26, 1929. American Journal of Mathematics, vol. 52, No. 2, pp. 293-304; April, 1930.

- An extended theory of Lucas' functions. Read Oct. 26, 1929. Annals of Mathematics, (2),vol. 31, No. 3, pp. 419-448; July, 1930.

McCoy, N. H. Note on the existence of a positive function orthogonal to a given set of functions. Read Sept. 11, 1930. This Bulletin, vol. 36, No. 12, pp. 878-882; Dec., 1930.

McDonnell, J. New criteria associated with Fermat's last theorem. Read Aug. 29, 1929. This Bulletin, vol. 36, No. 8, pp. 553-558; Aug., 1930.

MAIER, W. Elementary properties of the $t_{\nu}$-functions. Read April 18, 1930. Transactions of this Society, vol. 32, No. 4, pp. 905-911; Oct., 1930.

Mandelbrojt, S. See Gergen, J. J.

Manning, W. A. The primitive groups of class fourteen. Read May 7, 1927. American Journal of Mathematics, vol. 51, No. 4, pp. 619-652; Oct., 1929.

MARden, M. On the zeros of linear partial fractions. Read Dec. 27, 1928. Transactions of this Society, vol. 32, No. 1, pp. 81-109; Jan., 1930.

- On the zeros of certain rational functions. Read Dec. 30, 1929. Transactions of this Society, vol. 32, No. 4, pp. 658-668; Oct., 1930.

Mathewson, L. C. A simple proof of a theorem of Kronecker. Read Feb. 27, 1926. Journal für die Reine und Angewandte Mathematik, vol. 161, No. 4, p. 255 ; Dec. 30, 1929.

Michal, A. D. The differential geometry of a continuous infinitude of contravariant functional vectors. Read Dec. 30, 1929 . Proceedings of the National Academy of Sciences, vol. 16, No. 2, pp. 162-164; Feb., 1930.

- Projective functional tensors and other allied functionals. Read March 29, 1929. Proceedings of the National Academy of Sciences, vol. 16, No. 2, pp. 165-168; Feb., 1930.

- Geodesic coordinates of order $r$. Read Dec. 30, 1929. This Bulletin, vol. 36, No. 8, pp. 541-546; Aug., 1930.

Miller, F. H. An application of the method of parameters to linear partial differential equations. Read Oct. 26, 1929. This Bulletin, vol. 36, No. 2, pp. 120-126; Feb., 1930.

Miller, G. A. Inverse correspondences in automorphisms of abelian groups. Read Dec. 30, 1929. This Bulletin, vol. 36, No. 4, pp. 277-281; April, 1930.

Milne, W. E. The numerical determination of characteristic numbers. Read April 5, 1930. Physical Review, (2), vol. 35, No. 7, pp. 863-867; April 1, 1930.

Molina, E. C. The theory of probability: some comments on Laplace's Théorie Analytique. Read Feb. 22, 1930. This Bulletin, vol. 36, No. 6, pp. 369-392; June, 1930.

Moore, C. L. E. Geometry of a complex of curves in a Riemannian space of $n$ dimensions. Read Sept. 6, 1928. Journal of Mathematics and Physics of the 
Massachusetts Institute of Technology, vol. 8, No. 4, pp. 247-265; Dec., 1929.

See FrankLin, P.

Moore, C. N. On Gibbs's phenomenon for the developments in Bessel's functions. Read April 7, 1928, and Nov. 30, 1929. Transactions of this Society, vol. 32, No. 3, pp. 409-416; July, 1929.

Moore, T. W. On the resultant of two binary forms. Read March 30, 1929. Annals of Mathematics, (2), vol. 31, No. 2, pp. 185-189; May, 1930.

Morse, M. Closed extremals. Read Dec. 27, 1929. Proceedings of the National Academy of Sciences, vol. 15, No. 11, pp. 856-859; Nov., 1929.

- A generalization of the Sturm separation and comparison theorems in $n$-space. Read Dec. 27, 1928. Mathematische Annalen, vol. 103, No. 1, pp. 52-69; March, 1930.

- The foundations of a theory of the calculus of variations in the large in $m$-space (second paper). Read April 6, 1928. Transactions of this Society, vol. 32, No. 4, pp. 599-631; Oct., 1930.

Muckenhoupt, C. F. Vibrating systems and almost periodic functions. Read Dec. 27, 1928. Journal of Mathematics and Physics of the Massachusetts Institute of Technoloy, vol. 8, No. 3, pp. 163-199; Oct., 1929.

Murnaghan, F. D. Maxwell's theory of the layer dielectric. Read May 1, 1926. Journal of the American Institute of Electrical Engineers, vol. 46, No. 2, pp. 132-139; Feb., 1927.

- See Kaplan, C.

NeElley, J. H. Notes on the rational plane oscnodal quartic curve. Read Dec. 27, 1929. This Bulletin, vol. 36, No. 4, pp. 269-273; April, 1930.

- See Dorwart H. L.

Newman, P. See Feld, J. M.

Nowlan, F. S. On the direct product of a division and a total matric algebra. Read June 18, 1927. This Bulletin, vol. 36, No. 4, pp. 265-268; April, 1930.

OAKLEY, C. O. Differential equations containing absolute values of derivatives. Read Dec. 27, 1929. American Journal of Mathematics, vol. 52, No. 3, pp. 659-672; July, 1930.

Olson, H. L. Doubly divisible quaternions. Read Aug. 30, 1929. Annals of Mathematics, (2), vol. 31, No. 3, pp. 371-374; July, 1930.

ORE, O. Abriss einer arithmetischen Theorie der Galoisschen Körper. (Zweite Mitteilung.) Read April 7 and Dec. 27, 1928. Mathematische Annalen, vol. 102, No. 2, pp. 283-304; Oct., 1929.

- Sur les fonctions hypergéométriques de plusieurs variables. Read Feb. 22, 1930. Comptes Rendus de l'Académie des Sciences, vol. 189, No. 27, pp. 1238-1240; Dec. 30, 1929.

_ Einige Untersuchungen über endliche Körper. Read Dec. 27, 1929. Comptes Rendus du septième Congrès des Mathématiciens Scandinaves tenu à Oslo 19-22 Août 1929, pp. 65-67; Oslo, 1930.

- See Langdon, W. L.

Pall, G. On the number of representations of a square, or a constant times a square, as the sum of an odd number of squares. Read Nov. 29, 1929. 
Journal of the London Mathematical Society, vol. 5, No. 2, pp. 102-105; April, 1930.

PeEK, R. L. On the solution of certain cases of the general equation of diffusion. Read Dec. 27, 1929. Physical Review, (2), vol. 35, No. 5, pp. 554561; March 1, 1930.

Pierce, T. A. On an algorithm and its use in approximating roots of algebraic equations. Read June 21, 1929. American Mathematical Monthly, vol. 36, No. 10 , pp. 523-525; Dec., 1929.

Matrices whose characteristic equations are cyclic. Read Dec. 30, 1929. This Bulletin, vol. 36, No. 4, pp. 262-264; April, 1930.

Pierpont, J. Non-euclidean geometry, a retrospect. Read June 20, 1929. This Bulletin, vol. 36, No. 2, pp. 66-76; Feb., 1930.

Pixley, H. H. Discontinuous solutions in the problem of depreciation and replacement. Read April 6, 1928. American Journal of Mathematics, vol. 52, No. 4, pp. 851-862; Oct., 1930.

Poor, V. C. Residues of polygenic functions. Read Nov. 30, 1929. Transactions of this Society, vol. 32, No. 2, pp. 216-222; April, 1930.

Poritsky, H. On certain polynomial and other approximations to analytic functions. Read Aug. 29, 1929. Proceedings of the National Academy of Sciences, vol. 16, No. 1, pp. 83-85; Jan., 1930.

Post, E. L. Generalized differentiation. Read Oct. 27, 1923. Transactions of this Society, vol. 32, No. 4, pp. 723-781; Oct., 1930.

PRASAD, G. On the nature of $\theta$ in the mean-value theorem of the differential calculus. Read Feb. 25, 1928. This Bulletin, vol. 36, No. 4, pp. 289-291; April, 1930.

Putnam, R. G. Note on separability. Read Sept. 6, 1928. This Bulletin, vol. 36, No. 2, pp. 127-129; Feb., 1930.

- Note on the equivalence of certain properties of abstract sets. Read Dec. 27, 1929. This Bulletin, vol. 36, No. 10, pp. 653-654; Oct., 1930.

RaINICH, G. Y. On a decomposition of a quaternary quadratic form. Read Aug. 27, 1929. This Bulletin, vol. 36, No. 2, pp. 107-111; Feb., 1930.

RAwLES, T. H. On the inverse problem in the calculus of variations. Read Feb. 23, 1929. American Journal of Mathematics, vol. 52, No. 1, pp. 72-74; Jan., 1930.

REID, W. T. Properties of solutions of an infinite system of ordinary linear differential equations of the first order with auxiliary boundary conditions. Read Dec. 1, 1928, and March 29, 1929. Transactions of this Society, vol. 32, No. 2, pp. 284-318; April, 1930.

RIDER, P. R. On the distribution of the ratio of mean to standard deviation in small samples from non-normal universes. Read March 30, 1929. Biometrika, section A, vol. 21, parts 1-4, pp. 124-143; Dec., 1929.

Ritr, J. F. On a certain ring of functions of two variables. Read Oct. 26, 1929. Transactions of this Society, vol. 32, No. 2, pp. 155-170; April, 1930.

- Manifolds of functions determined by systems of algebraic differential 
equations. Read April 18, 1930. Transactions of this Society, vol. 32, No. 4, pp. 569-598; Oct., 1930.

Roberts, J. H. On a problem of C. Kuratowski concerning upper semi-continuous collections. Read Dec. 27, 1928. Fundamenta Mathematicae, vol. 14 , pp. 96-102; 1929.

— On a problem of Menger concerning regular curves. Read June 21, 1929. Fundamenta Mathematicae, vol. 14, pp. 327-333; 1929.

- Concerning non-dense plane continua. Read Dec. 28, 1927, and Dec. 27, 1928. Transactions of this Society, vol. 32, No. 1, pp. 6-30; Jan., 1930.

- Concerning collections of continua not all bounded. Read June 21, 1929. American Journal of Mathematics, vol. 52, No. 3, pp. 551-562; July, 1930.

- A note concerning cactoids. Read April 18, 1930. This Bulletin, vol. 36, No. 12, pp. 894-896; Dec., 1930.

- Concerning atriodic continua. Read April 6, 1928. Monatshefte für Mathematik und Physik, vol. 37, No. 2, pp. 223-230; 1930.

Robison, G. M. Summability of infinite products. Read Dec. 28, 1927. American Journal of Mathematics, vol. 51, No. 4, pp. 653-660; Oct., 1929.

Rosinger, K. E. Concerning the symbols $\phi x$ and $\phi \hat{x}$. Read Dec. 31, 1928. Annals of Mathematics, (2), vol. 31, No. 2, pp. 181-184; May, 1930.

Rотн, W. E. On the unilateral equation in matrices. Read Aug. 29, 1929. Transactions of this Society, vol. 32, No. 1, pp. 61-80; Jan., 1930.

RUtLedGe, G. A necessary and sufficient condition for convergence of a sequence of Lagrange polynomials. Read Feb. 22, 1930. Journal of Mathematics and Physics of the Massachusetts Institute of Technology, vol. 9, No. 4, pp. 261-277; Sept., 1930.

Schultz, H. The standard error of a forecast from a curve. Read Dec. 30, 1929. Journal of the American Statistical Association, vol. 25, No. 170, pp. 139-185; June, 1930.

Schwatt, I. J. Expressions for the Euler numbers obtained by expanding $\sec x$ by means of Maclaurins theorem. Read Dec. 29, 1920. Mathematische Zeitschrift, vol. 31, No. 1, pp. 151-158; Nov., 1929.

- Methods for the summation of certain families of series. Read Oct. 31, 1925. Monatshefte für Mathematik und Physik, vol. 37, No. 2, pp. 231$240 ; 1930$.

Seely, C. E. Note on kernels of positive type. Read March 30,1929. Annals of Mathematics, (2), vol. 31, No. 1, pp. 32-34; Jan., 1930.

Sharpe, F. R. Plane involutions of order three or four. Read Dec. 27, 1929. American Journal of Mathematics, vol. 52, No. 2, pp. 397-398; April, 1930.

Shoнat, J. A. (Сhokhate, J.). On the polynomial and trigonometric approximation of measurable bounded functions on a finite interval. Read Nov. 30, 1928. Mathematische Annalen, vol. 102, No. 1, pp. 157-175; July, 1929.

- Sur les intégrales de Stieltjes. Read Dec. 27, 1929. Comptes Rendus de l'Académie des Sciences, vol. 189, No. 17, pp. 618-620; Oct. 21, 1929.

— Sur le polynome de Tchebycheff de la meilleure approximation. Read Dec. 27, 1929. Comptes Rendus de l'Académie des Sciences, vol. 189, No. 21, pp. 829-831; Nov. 18, 1929.

_ Inequalities for moments of frequency functions and for various statistical 
constants. Read Dec. 27, 1929. Biometrika, section B, vol. 21, Nos. 1-4, pp. 361-370; Dec., 1929.

Simmons, H. A. On the limit of the ratio of an arc to its chord. Read Sept. 7, 1928. American Mathematical Monthly, vol. 36, No. 7, pp. 382-384; Aug.-Sept., 1929.

- Maximum numbers associated with the diophantine equation $\sum\left(1 / x_{1} x_{2}\right.$ $\left.\cdots x_{n-1}\right)=b /[(m+1) b-1]$. Read Aug. 29, 1929. American Mathematical Monthly, vol. 37, No. 3, pp. 137-142; March, 1930.

Sisam, C. H. On varieties of three dimensions with six right lines through each point. Read Aug. 27, 1929. American Journal of Mathematics, vol. 52, No. 3, pp. 607-610; July, 1930.

SmaIL, L. L. A simplified derivation of the fundamental properties of double sequences. Read Dec. 28, 1926. Messenger of Mathematics, vol. 58, Nos. 7 and 8, pp. 106-112, 113-115; Nov. and Dec., 1928.

Smiley, W. G. See Evans, G. C.

Smith, C. D. On generalized Tchebycheff inequalities in mathematical statistics. Read April 6, 1928. American Journal of Mathematics, vol. 52, No. 1, pp. 109-126; Jan., 1930.

Smith, R. G., and Stouffer, E. B. Derivation of certain relations involving sums of determinants. Read April 2, 1926. University of Kansas Science Bulletin, vol. 19, No. 1, pp. 5-15; Nov., 1929.

SNyder, V. The simplest involutorial transformation contained multiply in a line complex. Read April 6, 1928. This Bulletin, vol. 36, No. 2, pp. 89-93; Feb., 1930.

- On an involutorial transformation found by Montesano. Read Dec. 27, 1929. Annals of Mathematics, (2), vol. 31, No. 3, pp. 335-343; July, 1930.

Stafford, E. T., and Vandiver, H. S. Determination of some properly irregular cyclotomic fields. Read Dec. 27, 1928. Proceedings of the National Academy of Sciences, vol. 16, No. 2, pp. 139-149; Feb., 1930.

Starcher, G. W. A solution of a simple functional equation as a basis for readily obtaining certain fundamental formulas in the theory of elliptic functions. Read April 18, 1930. This Bulletin, vol. 36, No. 8, pp. 577-581; Aug., 1930.

Stone, M. H. Linear transformations in Hilbert space. III. Operational methods and group theory. Read Dec. 27, 1928. Proceedings of the National Academy of Sciences, vol. 16, No. 2, pp. 172-175; Feb., 1930.

Stouffer, E. B. See Smith, R. G.

Struik, D. J. Correlation and group theory. Read Sept. 6, 1928. This Bulletin, vol. 36, No. 12, pp. 869-878; Dec., 1930.

Swingle, P. M. Generalized indecomposable continua. Read Oct. 26, 1929. American Journal of Mathematics, vol. 52, No. 3, pp. 647-658; July, 1930.

TAMarkin, J. D. A lemma of the theory of linear differential systems. Read Oct. 26, 1929. This Bulletin, vol. 36, No. 2, pp. 99-102; Feb., 1930.

The notion of Green's function in the theory of integro-differential equations, II. Read Dec. 28, 1926. Transactions of this Society, vol. 32, No. 4, pp. 860-868; Oct., 1930. 
See Hille, E.

Thielman, H. P. On new integral addition theorems for Bessel functions. Read March 29, 1929. Proceedings of the National Academy of Sciences, vol. 15, No. 9, pp. 731-733; Sept., 1929.

On new integral addition theorems for Bessel functions and series of the hypergeometric type. Read March 29, 1929. Annals of Mathematics, (2), vol. 31, No. 2, pp. 193-206; May, 1930.

Tномpson, L. T. E. Ballistic engineering problems: empirical summaries. Read Dec. 27, 1928. United States Naval Institute Proceeedings, vol. 56, No. 327, pp. 411-418; May, 1930.

Trjitzinsky, W. J. On quasi-analytic functions. Read June 18, 1927, and April 7 and Dec. 27, 1928. Annals of Mathematics, (2), vol. 30, No. 4, pp. 526-546; Oct., 1929.

On composition of singularities. Read March 29, 1929. Transactions of this Society, vol. 32, No. 2, pp. 196-215; April, 1930.

USPENSKy, J. V. On the reduction of the indefinite binary quadratic forms. Read April 5, 1930. This Bulletin, vol. 36, No. 10, pp. 710-718; Oct., 1930.

Vandiver, H. S. Summary of results and proofs on Fermat's last theorem (fourth paper). Read Aug. 29, $1929 . \quad$ Proceedings of the National Academy of Sciences, vol. 15, No. 2, pp. 108-109; Feb., 1929.

- On the first case of Fermat's last theorem. Read March 30, 1929. Annals of Mathematics, (2), vol. 30, No. 4, pp. 552-558; Oct., 1929.

- An algorithm for transforming the Kummer criteria in connection with Fermat's last theorem. Read March 30,1929. Annals of Mathematics, (2), vol. 30, No. 4, pp. 559-577; Oct., 1929.

- A new theory of the representation of integers as definite quadratic forms. Read Sept. 11, 1925. Annals of Mathematics, (2), vol. 31, No. 1, pp. 117122; Jan., 1930.

- Some properties of a certain system of independent units in a cyclotomic field. Read Aug. 29, 1929. Annals of Mathematics, (2), vol. 31, No. 1, pp. 123-125; Jan., 1930.

- On power characters of singular integers in a properly irregular cyclotomic field. Read Aug. 29, 1929. Transactions of this Society, vol. 32, No. 3, pp. 391-408; July, 1930.

- See Stafford, E. T.

VAsilesco, F. See Kellogg, O. D.

WALSH, J. L. Boundary values of an analytic function and the Tchebycheff method of approximation. Read March 30, 1929. Proceedings of the National Academy of Sciences, vol. 15, No. 10, pp. 799-802; Oct., 1929.

- On the overconvergence of sequences of polynomials of best approximation. Read Feb. 22, 1930. Proceedings of the National Academy of Sciences, vol. 16, No. 4, p. 297; April, 1930.

- Boundary values of an analytic function and the Tchebycheff method of approximation. Read March 30, 1929. Transactions of this Society, vol. 32, No. 3, pp. 335-390; July, 1930.

On the overconvergence of sequences of polynomials of best approxima- 
tion. Read Feb. 22, 1930. Transactions of this Society, vol. 32, No. 4, pp. 794-816; Oct., 1930.

WARD, L. E. Series associated with certain irregular third-order boundary value problems. Read April 7, 1928, and March 29 and Aug. 29, 1929. Transactions of this Society, vol. 32, No. 3, pp. 544-557; July, 1930.

WARD, M. Postulates for the inverse operations in a group. Read April 5, 1930. Transactions of this Society, vol. 32, No. 3, pp. 520-526; July, 1930.

WEAR, L. E. On an extension of the idea of line and surface integrals. Read Oct. 30, 1926. Tôhoku Mathematical Journal, vol. 32, Nos. 3-4, pp. 286291; June, 1930.

Weiss, M. J. On groups defined by $A^{q}=1, B^{-1} A B=A^{x}, B^{Q}=A^{e}$. Read Dec. 30, 1929. Proceedings of the National Academy of Sciences, vol. 15, No. 12, pp. 903-905; Dec., 1929.

- The limit of transitivity of a substitution group. Read Aug. 29, 1929. Transactions of this Society, vol. 32, No. 2, pp. 262-283; April, 1930.

Whyburn, G. T. On simple closed curves. Read June 21, 1929. Bulletin Internationale de l'Académie Polonaise des Sciences et des Lettres, Classe des Sciences Mathématiques et Naturelles, ser. A, 1929, No. 6A, pp. 280-283; June, 1929.

Concerning points of continuous curves defined by certain im kleinen properties. Read June 2, 1928. Mathematische Annalen, vol. 102, No. 2, pp. 313-336; Oct., 1929.

Continuous curves and arc-sums. Read Dec. 27, 1928. Fundamenta Mathematicae, vol. 14, pp. 103-106; 1929.

- A generalized notion of accessibility. Read April 7, 1928. Fundamenta Mathematicae, vol. 14, pp. 311-326; 1929.

Cut points of connected sets and of continua. Read Dec. 27, 1928. Transactions of this Society, vol. 32, No. 1, pp. 147-154; Jan., 1930.

- A continuum every subcontinuum of which separates the plane. Read Feb. 22, 1930. American Journal of Mathematics, vol. 52, No. 2, pp. 319330; April, 1930.

The rationality of certain continuous curves. Read Feb. 22, 1930. This Bulletin, vol. 36, No. 8, pp. 522-524; Aug., 1930.

- On the structure of connected and connected im kleinen point sets. Read Sept. 6 and Dec. 27, 1928. Transactions of this Society, vol. 32, No. 4, pp. 926-943; Oct., 1930.

- On the set of all cut points of a continuous curve. Read June 21, 1929. Fundamenta Mathematicae, vol. 15, pp. 185-194; 1930.

Whyburn, W. M. On self-adjoint, ordinary differential equations of the fourth order. Read Feb. 25, 1928. American Journal of Mathematics, vol. 52, No. 1, pp. 170-196; Jan., 1930.

On related difference and differential sytems. Read Nov. 29, 1929. This Bulletin, vol. 36, No. 2, pp. 94-98; Feb., 1930.

- Functional properties of the solutions of differential systems. Read June 21, 1929. Transactions of this Society, vol. 32, No. 3, pp. 502-508; July, 1930. 
A set of cyclically related functional equations. Read April 5, 1930. This Bulletin, vol. 36, No. 12, pp. 863-868; Dec., 1930.

WidDER, D. V. Singular points of functions which satisfy the partial differential equation of the flow of heat. Read Dec. 27, 1929. This Bulletin, vol. 36, No. 10, pp. 687-694; Oct., 1930.

WILDER, R. L. Concerning perfect continuous curves. Read Aug. 30, 1929. Proceedings of the National Academy of Sciences, vol. 16, No. 3, pp. 233240; March, 1930.

- A converse of the Jordan-Brouwer separation theorem in three dimensions. Read Dec. 31, 1928, and March 29 and Aug. 30, 1929. Transactions of this Society, vol. 32, No. 4, pp. 632-657; Oct., 1930.

Williams, K. P. The constants of the disturbing function. Read April 19, 1930. American Journal of Mathematics, vol. 52, No. 3, pp. 571-584; July, 1930.

Williamson, J. Note on the simultaneous system of two quadratic quaternary forms. Read Dec. 27, 1928. Journal of the London Mathematical Society, vol. 4, No. 3, pp. 182-183; July, 1929.

— The complete system of two quaternary quadratics. Read Dec. 27, 1928. American Journal of Mathematics, vol. 51, No. 4, pp. 565-576; Oct., 1929. A special prepared system for two quadratics in $n$ variables. Read Dec. 27, 1929. American Journal of Mathematics, vol. 52, No. 2, pp. 399-412; April, 1930.

Wilson, W. A. A property of continua equivalent to local connectivity. Read Aug. 30, 1929. This Bulletin, vol. 36, No. 2, pp. 85-88; Feb., 1930.

- On the Phragmén-Brouwer theorem. Read Oct. 26, 1929. This Bulletin, vol. 36, No.2, pp. 111-114; Feb., 1930.

- A property of unbounded continua, with applications. Read Dec. 27, 1929. American Journal of Mathematics, vol. 52, No. 3, pp. 537-542; July, 1930.

WINGer, R. M. Trinomial curves and monomial groups. Read Dec. 28, 1927. American Journal of Mathematics, vol. 52, No. 2, pp. 377-396; April, 1930.

ZARISKI, O. On the moduli of algebraic functions possessing a given monodromie group. Read Dec. 27, 1929. American Journal of Mathematics, vol. 52, No. 1, pp. 150-170; Jan., 1930.

ZipPIN, L. On continuous curves and the Jordan curve theorem. Read Aug. 30, 1929. American Journal of Mathematics, vol. 52, No. 2, pp. 331-350; April, 1930. 